\title{
Effects of nifedipine on gastric acid secretion and gastrin release in man
}

\author{
K E L MCCOLL, N M M BUCHANAN, G LAFERLA, J HEARNS, \\ K BUCHANAN, AND G P CREAN \\ From the Gastrointestinal Centre, Southern General Hospital, Glasgow and University Department of \\ Medicine, Royal Victoria Infirmary, Belfast
}

SUMMARY As calcium is important in the regulation of gastric acid secretion and gastrin release, we have examined the effect of the calcium antagonist nifedipine on these processes in man. Nifedipine $30 \mathrm{mg}$ orally inhibited basal acid output by $37 \%(\mathrm{p}<0.025)$ and that stimulated by low infusion rates of pentagastrin - that is, 0.031 and $0.062 \mu \mathrm{g} / \mathrm{kg} / \mathrm{h}$ by $44 \%(\mathrm{p}=0.05)$ and $39 \%$ $(\mathrm{p}<0.02)$ respectively. On increasing the pentagastrin infusion rate the inhibition was surmounted suggesting it was competitive in type. Nifedipine did not affect basal or Oxo meal stimulated gastrin concentrations in normal volunteers nor did it affect resting serum gastrin or calcium stimulated increase in gastrin in a single patient with Zollinger-Ellison syndrome. These findings are consistent with the transmembrane flux of calcium ions being involved in basal and pentagastrin stimulated acid secretion in man.

Calcium ions play an important role in stimulus secretion coupling in many exocrine and endocrine tissues, ' and there is evidence that both gastric acid secretion and gastrin release are calcium dependent processes. $^{2+}$ The administration of calcium, either intravenously or intragastrically, stimulates acid secretion and increases circulating concentrations of gastrin. ${ }^{-\infty}$ The rise in serum gastrin stimulated by intravenous calcium is particularly marked in patients with the Zollinger-Ellison syndrome. ${ }^{9}$ In contrast, hypocalcaemia, whether because of hypoparathyroidism or whether induced by EDTA, is associated with decreased gastric acid secretion which can be restored by correcting the serum calcium concentration."

Verapamil, which is a calcium channel blocker decreases gastric acid secretion in man, 112 and inhibits calcium stimulated gastrin release in isolated canine antral mucosa. ${ }^{13}$ It has also been shown to interfere with the secretion of the gastrointestinal hormones, glucagon and insulin in laboratory animals, ${ }^{1+15}$ and to inhibit serotonin secretion in a patient with the carcinoid syndrome. ${ }^{16}$

We wish to report our studies of the effect of the

Address for correspondence: Dr Kenneth E L McColl, University Dept Medicine, Western Infirmary. Glasgow, G11 6NT.

Received for publication 14 August 1986. calcium channel blocker nifedipine on gastric acid secretion and gastrin release in healthy volunteers and on resting and calcium stimulated gastrin release in a patient with the Zollinger-Ellison syndrome.

\section{Methods}

SUBJECTS

\section{Acid secretion studies}

Twelve healthy male volunteers of mean age 34 years (range 26-44) and mean weight $73 \mathrm{~kg}$ (range 62-83) were studied. None were smokers. Three experiments were done in a double blind randomised crossover fashion comparing the effects of nifedipine and placebo on acid secretion stimulated by different doses of pentagastrin. The same 12 subjects participated in each experiment.

In the first experiment they reported fasted at $9 \mathrm{am}$ on two days, at least seven days apart, and received in randomised order $3 \times 10 \mathrm{mg}$ capsules of nifedipine or placebo with $100 \mathrm{ml}$ water. At 45 minutes postdosing, a Salem sump 18 gauge nasogastric tube was passed and a constant intragastric infusion of phenol red (12 $\mathrm{ml} / \mathrm{h}$ ) started via a side tube. From 60 to 105 minutes postdosing, $3 \times 15$ minute basal collections of gastric juice were obtained by constant suction. At 105 
minutes an intravenous infusion of pentagastrin $(0.992 \mu \mathrm{g} / \mathrm{kg} / \mathrm{h})$ was started and three further 15 minute collections obtained. The second experiment was done in an identical fashion, except that the pentagastrin infusion rate was $0 \cdot 031 \mu \mathrm{g} / \mathrm{kg} / \mathrm{h}$. In the third experiment pentagastrin was infused at a rate of $0 \cdot 062 \mu \mathrm{g} / \mathrm{kg} / \mathrm{h}$ from 105 to 150 minutes postdosing and then at $0.248 \mu \mathrm{g} / \mathrm{kg} / \mathrm{h}$ from 150 to 195 minutes when a further $3 \times 15$ minute collections were obtained.

The volume of each collection was recorded and its $\mathrm{H}^{+}$concentration measured by titration against $0 \cdot 1$ $\mathrm{NNaOH}$. The phenol red concentration in the gastric aspirate was measured spectrophotometrically and the sodium concentration by flame photometry and these values were used to correct for gastroduodenal loss and reflux according to the method of McCloy. ${ }^{17}$ The first 15 minute collection obtained after starting pentagastrin or increasing its infusion rate was discarded.

\section{Gastrin studies}

The effect of nifedipine on basal and meal stimulated gastrin release was studied in a further nine healthy male volunteers. Their mean age was 31 years (range 23-36) and mean weight $78 \mathrm{~kg}$ (range 65-87). The subjects reported fasted at 9 am on two days, one week apart, and received either $3 \times 10 \mathrm{mg}$ nifedipine capsules or placebo with $100 \mathrm{ml}$ water in randomised double blind order. Venous blood samples for gastrin estimation were obtained at $+15 \mathrm{~min},+30 \mathrm{~min},+45$ $\mathrm{min}$, and $+60 \mathrm{~min}$ after dosing. Immediately after the 60 minute samples they drank an Oxo meal consisting of two Oxo cubes dissolved in $200 \mathrm{ml}$ water at $45^{\circ} \mathrm{C}$ over 10 minutes. Further blood samples for gastrin estimation were obtained at seven minute intervals

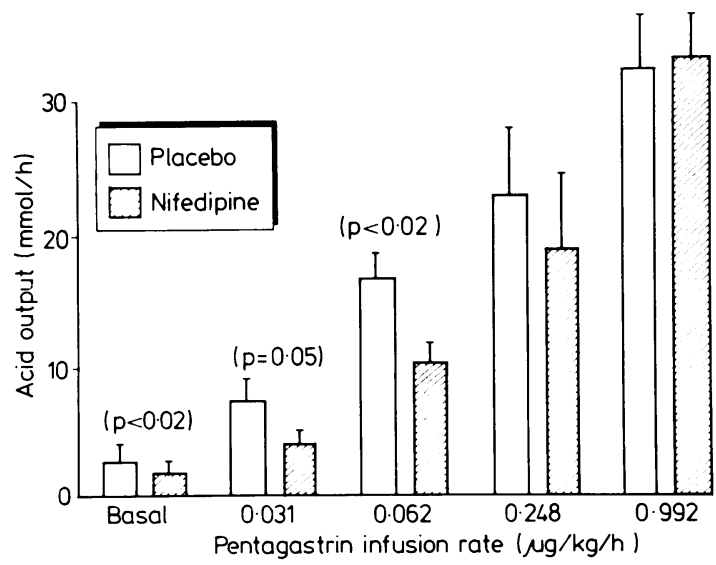

Fig. 1 Effects of nifedipine $30 \mathrm{mg}$ orally on basal and pentagastrin stimulated gastric acid secretion. Data expressed as mean $\pm S E M$. over the first 35 minutes after starting the meal and then at 15 minute intervals for a further 45 minutes.

The effect of nifedipine on the resting and calcium stimulated serum gastrin concentrations was studied in a 27 year old woman with the Zollinger-Ellison syndrome caused by a pancreatic gastrinoma. A subtotal gastrectomy had been carried out two years earlier. The patient was not on any medication at the time of the study.

Studies were done on two separate days comparing nifedipine and placebo in a single blind fashion. She reported fasted at 9 am and after lying relaxed for 30 minutes received $3 \times 10 \mathrm{mg}$ nifedipine capsules or placebo with $100 \mathrm{ml}$ water. Blood samples were obtained at $+30 \mathrm{~min},+60 \mathrm{~min}$ and immediately after dosing. At one hour postdosing an intravenous infusion of calcium gluconate $(4 \mathrm{mg} / \mathrm{kg} / \mathrm{h})$ was started and further blood samples obtained at 30-minute intervals for three hours. The serum gastrin estimation was undertaken by radioimunoassay using antibody 0098 as described by Ardill. ${ }^{18}$

Statistical comparisons were performed using the Wilcoxon's paired samples signed-rank test. The study was approved by the Hospital Ethical Committee.

\section{Results}

ACID SECRETION STUDIES

In the healthy volunteers, the basal acid output (mean \pm 1 SEM) after nifedipine was decreased at $1.8 \pm 0.5 \mathrm{mmol} / \mathrm{h}$ compared with $2.84 \pm 0.54 \mathrm{mmol} / \mathrm{h}$ following placebo $(p<0 \cdot 025)$ (Fig. 1). Acid output stimulated by low doses of pentagastrin was also inhibited by nifedipine. Compared with placebo, nifedipine $30 \mathrm{mg}$ decreased acid output stimulated with pentagastrin $0.031 \mu \mathrm{g} / \mathrm{kg} / \mathrm{h}$ by a mean of $44 \%$ $(p=0.05)$, with pentagastrin $0.062 \mu \mathrm{g} / \mathrm{kg} / \mathrm{h}$ by $39 \%$ $(\mathrm{p}<0.02)$, and with pentagastrin $0.248 \mu \mathrm{g} / \mathrm{kg} / \mathrm{h}$ by $17 \%$ (NS). Nifedipine did not inhibit acid output stimulated by high dose pentagastrin $(0.992$ $\mu \mathrm{g} / \mathrm{kg} / \mathrm{h})$. The decrease in basal acid output and that stimulated by low doses of pentagastrin was due to a decrease in both the volume and acidity of the gastric juice.

GASTRIN STUDIES

In the healthy volunteers after placebo treatment, the basal gastrin concentration (mean \pm 1 SEM) was $16 \pm 5 \mathrm{pmol} / \mathrm{l}$ and this rose to a maximum detected value of $41 \pm 10 \mathrm{pmol} / \mathrm{l}$ at 14 minutes after starting the meal, returning to basal values within one hour (Fig. 2). After nifedipine, the mean gastrin concentrations were similar to the placebo values at each time point studied. When the gastrin results were analysed as area under the plasma concentration-time curve, 


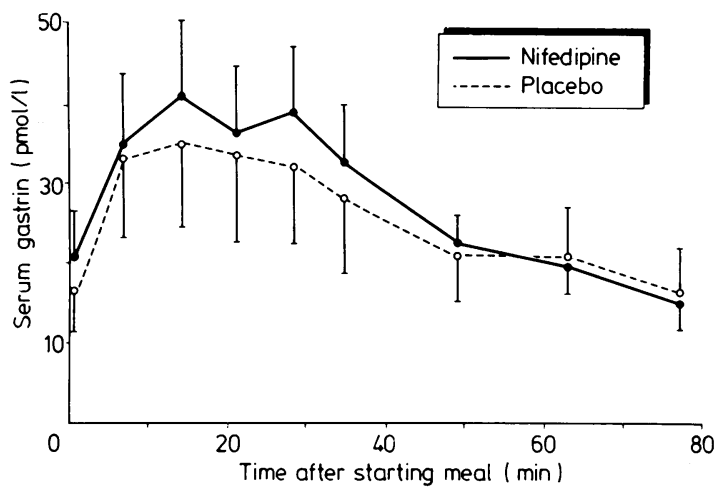

Fig. 2 Effect of nifedipine $30 \mathrm{mg}$ orally on serum gastrin levels under basal conditions and in response to Oxo meal. The time 0 sample was obtained before starting meal. Data expressed as mean $\pm S E M$.

there was again no difference between placebo and nifedipine pretreatments.

In the patient with Zollinger-Ellison syndrome, the mean resting gastrin concentration was 50000 $\mathrm{pmol} / \mathrm{l}$ and there was no change after nifedipine. With placebo pretreatment the three hour calcium infusion resulted in a progressive increase in the serum calcium from $2.1 \mathrm{mmol} / \mathrm{l}$ to $2.7 \mathrm{mmol} / \mathrm{l}$ and this was associated with a rise in the serum gastrin from $50000 \mathrm{pmol} / \mathrm{l}$ to $130000 \mathrm{pmol} / \mathrm{l}$ over the same time (Fig. 3). A similar increase in serum calcium and gastrin occurred with nifedipine pretreatment.

\section{Discussion}

This study shows that nifedipine inhibits gastric acid secretion in man. The corrections applied for gastroduodenal loss and reflux ensure that the observed reduction in acid output is not artefactual due to changes in gastroduodenal motility. Furthermore, other studies have confirmed that though nifedipine affects oesophageal motility ${ }^{19}$ it does not interfere with gastric emptying. ${ }^{2021}$

Although there have been no previous reports of the effect of nifedipine on gastric secretion in man studies have recently been reported concerning the calcium channel blocker verapamil. Kirkegaard et $a l^{\prime 2}$ showed that it inhibited acid secretion stimulated by low dose, but not high dose, infusions of 15 leucine synthetic human gastrin 1 , and that this inhibition could be overcome by the simultaneous infusion of calcium gluconate. Sonnenberg et al" found that verapamil inhibited acid secretion stimulated by both low and high dose infusions of pentagastrin as well as by the infusion of calcium
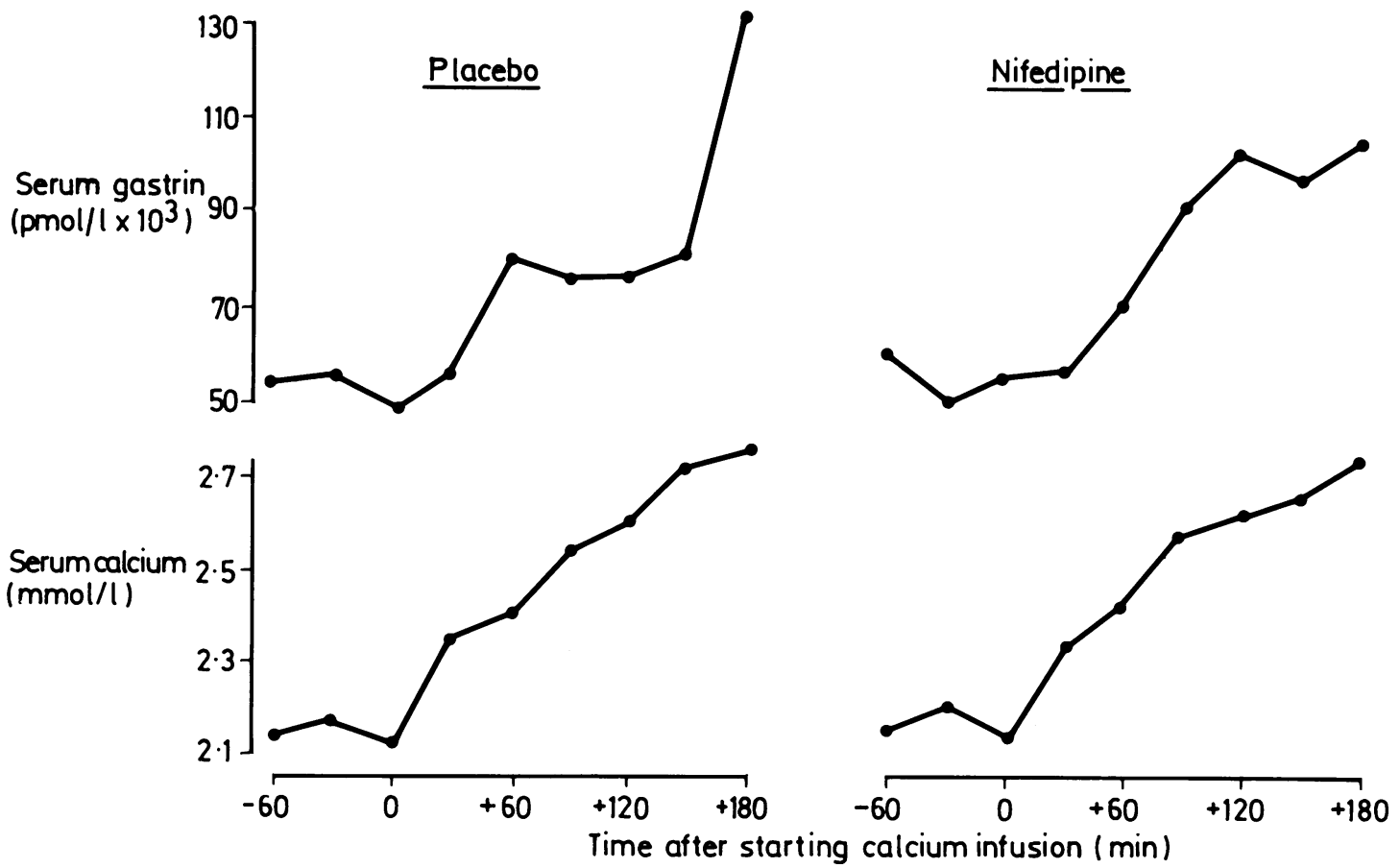

Fig. 3 Effect of nifedipine $30 \mathrm{mg}$ orally on resting serum gastrin level and gastrin response to calcium infusion in patient with Zollinger-Ellison syndrome. 
gluconate, but had no effect on basal acid secretion or that stimulated by bethanechol, sham feeding or the $\mathrm{H}_{2}$ agonist, impromidine. Levine et al ${ }^{22}$ found that verapamil had no inhibitory effect on acid secretion stimulated by a single near maximal infusion $(2 \mu \mathrm{g} / \mathrm{kg} / \mathrm{h})$ of pentagastrin. Our observation that nifedipine inhibits acid secretion in a similar manner to verapamil suggests that this effect is related to the common ability of these drugs to inhibit the transmembrane flux of calcium ions.

Although calcium has been known to be involved in the control of gastric acid secretion for many years, its precise role remains unclear. In vivo animal studies have shown that secretory responses to both acetylcholine and pentagastrin are dependent upon extracellular calcium. ${ }^{23}$ Isolated gastric glands also show an impaired secretory response to acetylcholine and gastrin when extracellular calcium is depleted but their response to histamine and dibutyryl cyclic AMP is unaffected. ${ }^{24}$ In isolated parietal cells, acid secretion stimulated by acetycholine, gastrin or histamine is impaired in the absence of calcium in the culture medium. ${ }^{25}$ The calcium channel blocking agent gallopamil and the metal lanthanum, which also blocks transmembrane calcium flux, both inhibit acid secretion by isolated parietal cells,${ }^{25.26}$ suggesting that transmembrane calcium flux is involved in the mediation of acid secretion by the parietal cells. Our findings with nifedipine together with the previous studies with verapamil"12 are consistent with transmembrane calcium flux being involved in gastrin mediated acid secretion in man. Calcium is also important in the release of histamine from mast cells within the gastric mucosa. ${ }^{27}$ In the intact animal, it is possible that nifedipine decreases acid secretion by inhibiting gastrin mediated histamine release from mast cells as well as by a direct effect on the parietal cell.

In both our study with nifedipine and that of Kirkegaard et al ${ }^{12}$ with verapamil the inhibition of acid secretion was most marked at low rates of pentagastrin/gastrin infusion and the inhibition was surmounted on increasing the stimulation. This pattern suggests that these calcium channel blockers inhibit gastrin mediated acid secretion in a competitive manner. This would be consistent with the observation of Levine $e t a l^{22}$ that verapamil did not inhibit acid secretion during near maximal stimulation with pentagastrin.

Although Sonnenberg et al " found that verapamil inhibited acid secretion stimulated by both low and high dose infusions of pentagastrin they were using particularly high doses of verapamil and the inhibition might have been overcome by further increasing the pentagastrin infusion rate.

Our studies of the effect of nifedipine on Oxo meal stimulated gastrin release in normal subjects showed no evidence of suppression of the gastrin response. Likewise, in the patient with the gastrinoma, nifedipine did not affect the resting gastrin level or inhibit the rise in the serum gastrin concentration during calcium infusion. In cultured rat antrum preparations, gastrin release has been shown to be inhibited by extracellular calcium depletion, nifedipine and verapamil. ${ }^{34}$ The lack of inhibition of gastrin release in our human studies may be related to the dose used and does not exclude a role for transmembrane calcium flux in gastrin release. As we selected the highest dose of nifedipine likely to be prescribed to patients, however, our study does exclude any clinically significant effect on gastrin release.

\section{References}

1 Douglas WW. The role of calcium in stimulus-secretion coupling. In: Case RM, Goebell H, eds, Stimulussecretion coupling in the gastrointestinal tract. Lancaster: MTP Press Limited, 1976: 17-29.

2 Christiansen J, Kirkegaard P, Olsen PS, Petersen B. Interaction of calcium and gastrin on gastric acid secretion in duodenal ulcer patients. Gut 1984; 25: 174-7.

3 Harty RF, Maico DG, Brown CM, McGuigan JE. Effects of calcium on cholinergic-stimulated gastrin release in the rat. Mol Cell Endocrinol 1984; 37: 133-8.

4 Harty RF, Maico DG, McGuigan JE. Role of calcium in antral gastrin release. Gastroenterology 1981; 80: 491-7.

5 Smallwood RA. Effect of intravenous calcium administration on gastric secretion of acid and pepsin in man. Gut 1967; 8: 592-8.

6 Christiansen J, Rehfeld JF, Stadil F. Interaction of calcium and magnesium on gastric acid secretion and serum gastrin concentration in man. Gastroenterology 1975; 68: 1140-3.

7 Reeder DD, Jackson M, Ban J, Glendinnen BG, David WD, Thompson JC. Influence of hypercalcaemia on gastric secretion and serum gastrin concentration in man. Ann Surg 1970; 172: 540-6.

8 Brodie MJ, Ganguli PC, Fine A, Thomson TJ. Effects of oral calcium gluconate on gastric acid secretion and serum gastrin concentration in man. Gut 1977; 18: 111-4.

9 Passaro E, Basso N, Walsh JH. Calcium challenge in the Zollinger-Ellison syndrome. Surgery 1972; 72: 60-7.

10 Donegan WL, Spiro HM. Parathyroids and gastric secretion. Gastroenterology 1960; 38: 750-60.

11 Sonnenberg A, Meckel F, Eckhardt U, Scholten Th. The effect of the calcium antagonist verapamil on gastric acid secretion in humans. Hepato-Gastroenterol 1984; 31: $8-84$.

12 Kirkegaard P, Christiansen J, Petersen B, Skov Olsen P. Calcium and stimulus-secretion coupling in gastric fundi mucosa. Scand J Gastroenterol 1982; 17: 533-8.

13 Fiddian-Green RG, Pittenger G, Kothary P, Vinik AI. Role of calcium in stimulus-secretion coupling of antral gastrin release. Endocrinology 1983; 112: 753-60. 
14 Devis G, Somers G, Van Obberghen E, Malaisse WJ. Calcium antagonists and islet function. Diabetes 1975; 24: 547-51.

15 Ohneda A, Kobayashi T, Nihei J. Effect of Ca antagonists, nifedipine, niladipine and verapamil on endocrine function of the pancreas. Tohoka J Exp Med 1983; 140: 153-9.

16 Ahlman H, Nilsson O, Gronstad K-O, Shoinik C, Tisell L-E, Dahlstrom A. Verapamil and diarrhoea in the carcinoid syndrome. Clinical and experimental observations on serotonin release. $B r J$ Cancer 1986; 54: 251-7.

17 McCloy RF. A basal-insulin-pentagastrin gastric secretion test. In: Baron JH, ed. Clinical tests of gastric secretion. London: Macmillan Press Ltd, 1978: 212-7.

18 Ardill JES. The measurement of gastrin by radioimmunoassay. Queen's University, Belfast: Thesis, 1973.

19 Richter JE, Dalton CB, Buice RG, Castell DO. Nifedipine: A potent inhibitor of contractions in the body of the human oesophagus. Gastroenterology 1985; 89: $549-54$.

20 Blackwell JN, Holt S, Heading RC. Effect of nifedipine on oesophageal motility and gastric emptying. Digestion 1981; 21: $50-6$.

21 Traube M, Lange RC, McAllister RG, McCallum RW. Effect of nifedipine on gastric emptying in normal subjects. Dig Dis Sci 1985; 30: 710-2.

22 Levine RA, Petakos S, Starr A, Eich RH. Effect of verapamil on basal and pentagastrin-stimulated gastric acid secretion. Clin Pharmacol Ther 1983; 34: 399-402.

23 Szelenyi I. Calcium, histamine and pentagastrin: Speculations about the regulation of gastric acid secretion at cellular level. Agents Actions 1980; 10: 187-90.

24 Berglindh T, Sachs G, Takeguchi N. $\mathrm{Ca}^{2+}-$ dependent secretagogue stimulation in isolated rabbit gastric glands. Am J Physiol 1980; 239: G91-G94.

25 Soll AH. Extracellular calcium and cholinergic stimulation of isolated canine parietal cells. J Clin Invest 1981; 68: $270-8$.

26 Sewing KF, Hanneman H. Calcium channel antagonists verapamil and gallopamil are powerful inhibitors of acid secretion in isolated and enriched guinea pig parietal cells. Pharmacology 1983; 27: 9-14.

27 Rangachari PK. Histamine release by gastric stimulants. Nature 1975; 253: 53-4. 